\title{
QUANTITATIVE SUSTAINABILITY ASSESSMENT OF SOLID WASTE MANAGEMENT IN SANA'A, YEMEN: CHALLENGES AND IMPROVEMENT MEASURES
}

\author{
ANAS AL-DAILAMI, IMRAN AHMAD AND NORHAYATI ABDULLAH* \\ Malaysia-Japan International Institute of Technology, Universiti Teknologi Malaysia, Jalan Sultan Yahya Petra, 54100, \\ Kuala Lumpur, Malaysia
}

*Corresponding author: norhayati@utm.my

Submitted final draft: 9 October $2020 \quad$ Accepted: 27 January 2021

http://doi.org/10.46754/jssm.2021.10.009

\begin{abstract}
Solid waste management is a vital area that needs to be addressed as it leads to a sustainable environment and welfare of the public. Unfortunately, in developing nations, improper solid waste management leads to the pollution of the environment and this affects people's health. The challenges and the improvement measures for solid waste vary for each country, depending on various factors, like topography, demography, and people's awareness. This study is based on the quantitative sustainability assessment of solid waste management in Sana'a, Yemen. The questionnaire survey has gone through a pilot study for a reliability test with 17 respondents. After the pilot study, the questionnaire survey was distributed randomly to the people living in Sana'a City. This study involved 106 respondents in total. The purpose of the pilot study was to check the questionnaire's reliability based on the Cronbach's Alpha value for both key challenges and the improvement measures of solid waste management. The Cronbach's Alpha value estimates of key challenges and improvement measures are 0.924 and 0.876 , respectively. This study found that the key challenges of sustainable solid waste management (SSWM) in Sana'a City are lack of awareness and glitch in recycling as the most critical aspects. Consequently, for this reason, it leads to a lack of encouragement for recycling, with the valuation of the mean being 4.10. Hence, effective and efficient improvement measures are to be practised in overcoming these issues. This paper incorporates the challenges and the improvement measures, which can be implemented to harmonise and sustain the environment and public welfare.
\end{abstract}

Keywords: Sustainability, solid waste, respondents, Sana'a, management.

\section{Introduction}

Global solid waste (SW) generation in 2010 amounted to 10.4 billion tonnes, and is expected to increase to an enormous amount of 148 billion tonnes by 2025 (Kameswari et al., 2007). Developing countries contributed about $56 \%$ of the global SW due to rapid and consistent increase in population, urbanisation and increased standards of living, which is in agreement with a previous study by AbarcaGuerrero et al. (2015). Proper solid waste disposal is increasingly important as every person is regarded as a possible generator of waste and thus an indirect contributor to solid waste-associated problems, whereby generation of wastes, the types of wastes generated and the ways these wastes are managed or disposed create multiple concerns related to solid waste management globally (Mukisa, 2009; Umeh et al., 2019). Solid waste is defined as unused solid materials, sewage sludge, domestic rubbish, wastes from manufacturing activities, discarded electronic devices, garden waste, etc (Aziz et al., 2016).

The collection, transportation, treatment, recycling, reusing or disposal of waste materials are a series of steps taken to achieve a sustainable approach in solid waste management (Manzhurov et al., 2019; Mugambwa \& Kizito, 2009; Okafor-Yarwood \& Adewumi, 2020). It is imperative to consider that waste management methods in developed countries are different from the ones in developing countries, and in urban and rural areas, as well as in residential and industrial processes (Mian et al., 2017). The amount and type of wastes from various 
resources are indicative of how the waste management processes might differ in terms of its compatibility and management efficiency. It should be appreciated that the context of the waste sources is needed to arrive at a suitable method (Mukisa, 2009). It is possible to convert adequate handling and treatment of the generated SW into potential operational expenditure (OPEX), while simultaneously reducing environmental burdens. This may further reduce the pressure on demands for natural resources, while creating new job markets (Suthar et al., 2016).

In economically and technologically developed countries, the enormous amount of daily municipal solid waste (MSW) is treated and disposed in a sustainable manner. Most of developed countries are already equipped with a well-established waste management system, which include processes such as composting, oxidation of anaerobic materials, burning, pyrolysis, gasification, and recycling. In modern sanitary areas, the remaining residues are disposed (Challcharoenwattana \& Pharino, 2015). Developed countries are also more privileged in terms of having access to knowledge and technology transfer, while simultaneously improving innovative approach in waste recycling and recovery of the potentially valuable resources from MSW (Suthar et al., 2016). However, in some developing countries, crude dumping and partial unregulated treatment of materials, fertilisers and energy recovery are commonly used to dispose the generated MSW (Harir et al., 2015).

Open Crude Dumping (OCD) in Yemen is the most common MSW management method. It is a conventional and unregulated waste disposal system, which was reported to cause detrimental effects to the environment worldwide (Ashraf et al., 2015). Waste disposal is an integral part of the MSWM framework that needs tremendous effort to reduce emissions from the ecosystem. Unfortunately, only major towns have some sort of waste disposal system (Alam \& Qiao, 2020). The disposal of MSW in unregulated and poorly managed dumpsites/landfills can have significant adverse economic, biodiversity and human health impacts (Liu et al., 2016; Rafizul et al., 2011). SWM is an issue of concern, even though the state have an effective solid waste management system (Warunasinghe \& Yapa, 2016). This study aims to provide a quantitative sustainability assessment of solid waste management in Sana'a, Yemen, to overcome the challenges and convey suggestions for improvements.

\section{Methodology}

\section{Methodology Adopted for Quantitative Assessment}

This analysis consists of three steps, namely (1) the initial stage of reporting, (2) the stage of data processing, and, (3) the final stage of reporting. The initial reporting stage contains a few tasks, such as the beginning problem, sustainable evaluation method and research overview. The performance of the analysis of the literature is the element of this report, which is (1) the latest solid waste management practices; (2) the key challenges of solid waste management; and, (3) the improvement measures of solid waste management.

The second phase of this research consists of the data collection steps, which covers (1) questionnaire design and (2) questionnaire reliability testing; (3) data collection; and, (4) data processing. In developing a questionnaire, the variables learned from the literature review were used. Prior to the data collection, a test on the questionnaire's reliability, also is known as the pilot analysis, was performed. After the minimum Cronbach's alpha rating of 0.6 has been obtained by the pilot sample, the questionnaire is considered valid.

If the value of the Cronbach's alpha from the pilot study is not more than the minimum value of passing of 0.6 , the questionnaire must be re-structured. In this study, collection of data is done out of the frequency percentage analysis, and relative index (RII) analysis is consequently important. 
The final reporting phase has two main activities: which are the data analysis and conclusion, respectively. The elements of variable have been identified based on the agreement level for every component and the significance of each component, based on RII analysis. The items are subsequently ranked from most important to least important based on the RII value. Figure 1 illustrates the questionnaire's suggested design.

\section{Design of Questionnaire and Reliability Coefficients}

The Cronbach's alpha test was used to calculate the reliability of the results, in which a Cronbach's alpha value of least 0.6 is required to confrm the questionnaire's reliability and to eliminate correcting or excluding some of the variables(Cronbach, 1951). The questionnaire was updated based on comments and suggestions from respondents. The coefficient distribution of the Cronbach's alpha and its degree of reliability are seen in Table 1.

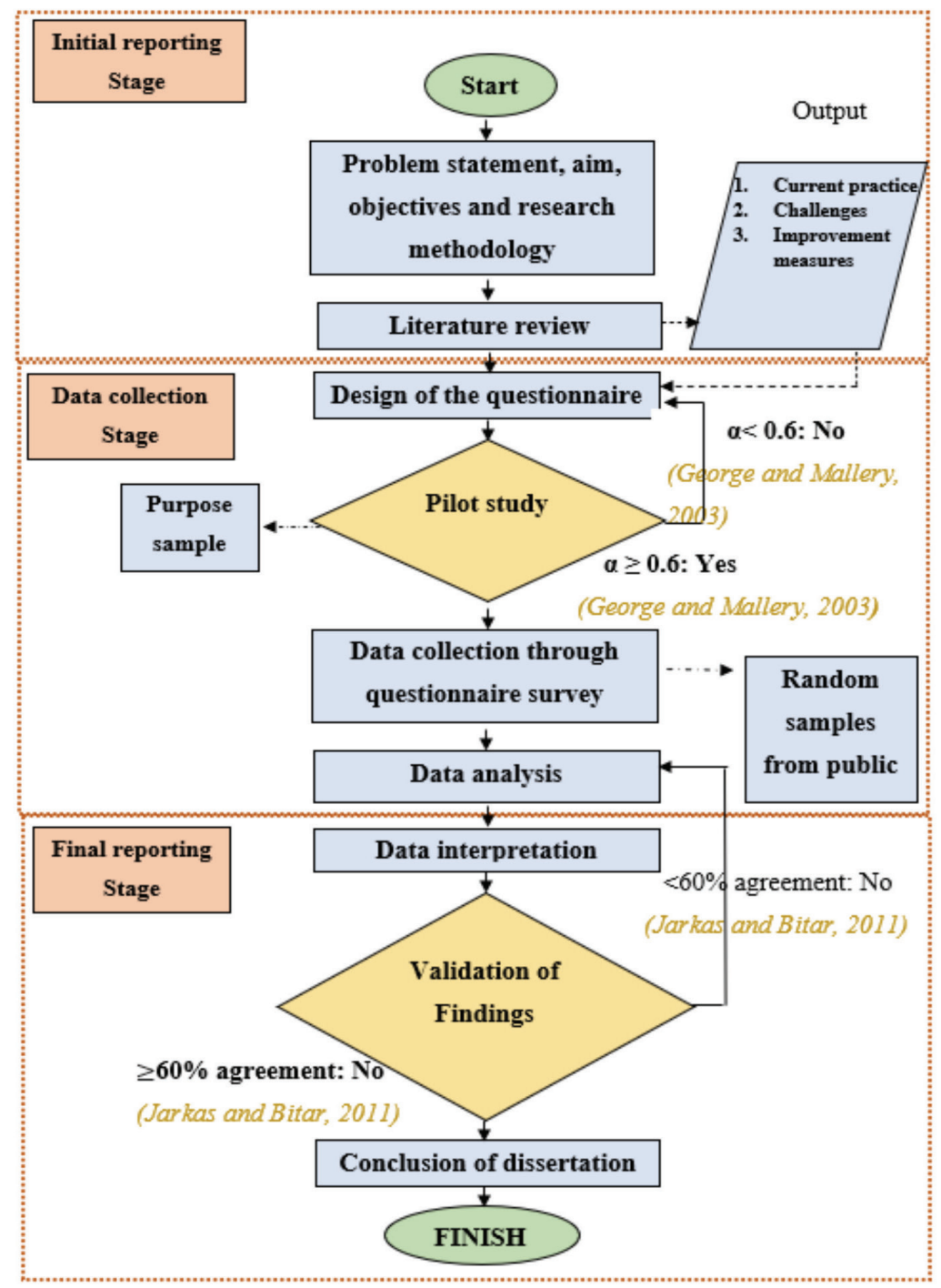

Figure 1: Flow of quantitative assessment 
Table 1: The value of Cronbach's alpha coefficient with its level of reliability

\begin{tabular}{ccc}
\hline & $\begin{array}{c}\text { Coefficient of Cronbach's } \\
\text { Alpha }\end{array}$ & $\begin{array}{c}\text { Reliability } \\
\text { Level }\end{array}$ \\
\hline A & More than 0.90 & Excellent \\
B & $0.80-0.89$ & Good \\
C & $0.70-0.79$ & Acceptable \\
D & $0.60-.69$ & Questionable \\
E & $0.50-0.59$ & Poor \\
F & Less than 0.59 & Unacceptable \\
\hline
\end{tabular}

Source: Adopted (D. George \& P. Mallery, 2003)

In this survey, the questionnaire was distributed via a web-based survey composed of four (4) sections, where the first section involves questions on demography, the second section is on the current practice of solid waste management, the third section is on challenges in sustaining solid waste management, and the fourth section is on the improvement measures to sustainable solid waste management. Table 2 summarises the variables and objectives of the questionnaire.

The answers are based on the Likert scale and consist of five level of measures that shows the statement of agreement from 1 to 5 as illustrated in Table 3.
Table 3: The agreement level based on the Likert scale from highest to least positive score

\begin{tabular}{lc}
\hline \multicolumn{1}{c}{ Answer } & Question's Score \\
\hline Strongly Agreed & 5 \\
Agreed & 4 \\
Neutral & 3 \\
Disagreed & 2 \\
Strongly Disagreed & 1 \\
\hline
\end{tabular}

\section{Types of Data}

The outcome of the study and data analysis has two major sources, primary and secondary data, respectively. The main data is a data gathered from the questionnaire sample and the data gathered from the previous analysis is secondary data. The questionnaire used for primary data collection is structured and tested for reliability based on the secondary data. The data would be correlated with the secondary data after reviewing the primary data.

\section{Primary Data}

Critical data is commonly viewed as data from the centre of information. The critical data is collected through the pilot study that involved 106 respondents, based on which 106 respondents were also included, as previously stated. The pilot summary was evaluated through a pilot test means, which was performed on $16 \%$ of the usual example, which are 17

Table 2: Variables of the performance management framework questionnaire and their objectives

\begin{tabular}{|c|c|c|c|}
\hline Section & Variable & Number & Objectives \\
\hline I & Demographic questions & 4 & Obtain the respondents' particulars \\
\hline II & $\begin{array}{l}\text { The current practice of } \\
\text { solid waste management }\end{array}$ & 9 & $\begin{array}{l}\text { The current practice of solid waste } \\
\text { management in Sana' a City, Yemen }\end{array}$ \\
\hline III & $\begin{array}{l}\text { Challenges in sustainable } \\
\text { solid waste management }\end{array}$ & 19 & $\begin{array}{l}\text { Challenges in sustainable solid waste } \\
\text { management in Sana'a City, Yemen }\end{array}$ \\
\hline IV & $\begin{array}{l}\text { Improvement measures } \\
\text { to sustainable solid waste } \\
\text { management }\end{array}$ & 9 & $\begin{array}{l}\text { Improvement measures to } \\
\text { sustainable solid waste management } \\
\text { in Sana'a City, Yemen }\end{array}$ \\
\hline TOTAL & & 77 & \\
\hline
\end{tabular}


people, before the critical information was gathered. This study uses a questionnaire survey methodology to examine the existing solid waste management activity in the city of Sana'a, the key challenges of solid waste management in the city of Sana'a, and solid waste management improvement measures. The survey is estimated as one of the most effective methods to include a broad number of people in order to produce a good outcome (McQueen \& Knussen, 2002; Taylor et al., 2015).

During a pilot study, $16 \%$ of the predicted sample was distributed (Connelly, 2008). Once the actual questionnaire survey is done, a pilot study was distributed to seventeen (17) respondents through a web-based survey. The purpose of examining the respondents was to understand the questionnaire, apart from evaluating whether the questionnaire is adequately detailed in obtaining the research details. A study claimed that the distribution of a questionnaire should be after conducting the pilot study to analyse the feasibility of the intended questionnaire, and to finalise the questionnaire concepts and wordings (Scheuren, 2004).

\section{Secondary Data}

Secondary data was collected from previous literature resources, such as journals, lectures, papers and publishing resources, increasing awareness of the concept of major problems for the management of solid waste and increasing measures for the management of solid waste. Secondary data is also important, aside from helping to achieve the objectives and goals of the research (Hart, 2018).

It was reported that due to affordability and ease, the released data should be used as much as necessary. For this cause, a thorough literature review or activity in this analysis, a systematic literature review, outsourcing of articles, conference proceedings, published theses, and academic papers have been carried out. The literature review play an important role as a secondary data that assists in a better perception of implementing sustainable solid waste management in terms of definition, characteristics, and methods. Furthermore, the literature review assisted in structuring the design of the questionnaire, solidifying the findings of the analysis (Fellows \& Liu, 2015).

\section{Data Analysis}

Both frequency percentage analysis and relative important index (RII) analysis are methods that analyse the data, while the tables illustrate the results.

\section{Frequency Percentage Analysis}

Frequency percentage analysis is a method that is used to analyse the questions of demographic in Section I of the questionnaire, which is identified in terms of standard deviation (SD) and means. The means level based on a scale that is illustrated in Table 4.

Table 4: The value of means based on the level of scale

\begin{tabular}{|c|c|}
\hline Level & Scale \\
\hline High & $\geq 3.00$ \\
\hline Low & $1.00-2.99$ \\
\hline
\end{tabular}

\section{Relative Important Index Analysis}

Table 5 illustrates the level of agreement in comparing with RII scale used in this study, which was derived from Jarkas and Bitar (2012), while the Relative Important Index (RII) analysis was used by Holt et al. (1996) and Nesan (1997). The values of RII are acquired by using the following formula:

Relative Important Index

$$
=\frac{\sum(1 X 1+2 X 2+3 X 3+4 X 4+5 X 5)}{5 \sum(X 1+X 2+X 3+X 4+X 5)}
$$

Where:

$X(1)=$ respondents who "strongly disagreed"

$X(2)=$ respondents who "disagreed"

$X(3)=$ respondents who "neutral"

$X(4)=$ respondents who "agreed"

$X(5)=$ respondents who "strongly agreed" 
Table 5: Agreement/importance level in comparing with the Relative Important Index (RII) scale

\begin{tabular}{|c|c|}
\hline Scale Range & $\begin{array}{l}\text { Level of Agreement/ } \\
\text { Importance }\end{array}$ \\
\hline RII less than $60 \%$ & Disagreed/not important \\
\hline $\begin{array}{l}\text { RII equal to or more } \\
\text { than } 60 \%\end{array}$ & Agreed/important \\
\hline
\end{tabular}

\section{Summary of Quantitative Assessment}

To sum up, the methodology of study is conclusive and should be emphasised as it will comprehensively affect the harmony of the study. The analysis of the data collected before the result interpretation phase used three methods; (1) frequency percentage analysis, (2) average index analysis; and (3) relative index analysis.
The model of the bowtie is a tool of management to plan actions that will be implemented (Hudson \& Hudson, 2019). Generally, the bowtie involves the left-hand side and right-hand side symmetrically, and it has coloured levels to shows the most and least of critical issues.

Figure 2 shows the conceptual bow tie, in which the left-hand side is filled up with key challenges and the right-hand side is filled up with improvement measures of sustainable solid waste management of this study. The adoption and modification of the conceptual bowtie is done by Cormier et al. (2019). In addition, the bow tie also points the coloured levels for each challenges and improvement measures. The coloured levels point to the rank of each item from a darker level to the lighter level (most critical to least critical), which was adopted from Zakaria (2015).

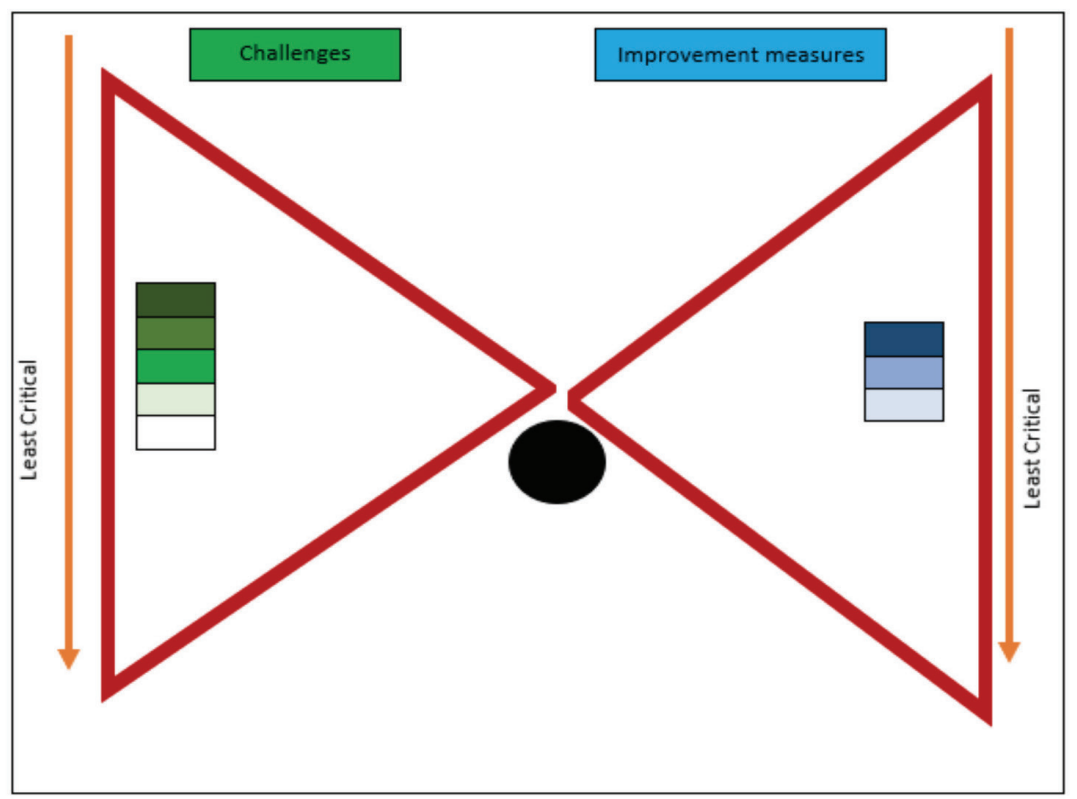

Legend

\begin{tabular}{|c|c|c|c|c|c|c|c|}
\hline $\begin{array}{c}\text { Challenge } \\
1\end{array}$ & $\begin{array}{c}\text { Challenge } \\
2\end{array}$ & $\begin{array}{c}\text { Challenge } \\
3\end{array}$ & $\begin{array}{c}\text { Challenge } \\
4\end{array}$ & $\begin{array}{c}\text { Challenge } \\
5\end{array}$ & $\begin{array}{c}\text { Improvement } \\
\text { Measure 1 }\end{array}$ & $\begin{array}{c}\text { Improvement } \\
\text { Measure 2 }\end{array}$ & $\begin{array}{c}\text { Improvement } \\
\text { Measure 3 }\end{array}$ \\
\hline & & & & & & & \\
\hline
\end{tabular}

Figure 2: Theoretical bowtie on challenges and improvement measures of sustainable solid waste management (Cormier et al., 2019; Zakaria, 2015) 


\section{Results and Discussion}

\section{Pilot Study}

The conducted pilot study was used to estimate the reliability test of the designed questionnaire survey. The reliability was evaluated using SPSS Statistics version 26 . The designed questionnaire was distributed to the public living in Sana'a City, Yemen. Table 6 summarises the results of the questionnaire's reliability test. The essential variables in the questionnaire were entirely answered by 17 respondents and achieved a Cronbach's alpha value of more than the 0.6 as suggested by Jett and George (2003). In addition, Tavakol and Dennick (2011) reported that a Cronbach's alpha value of more than 0.8 signifies high reliability.
Table 6 shows the Cronbach's alpha values for 2 variables based on the number of questions and respondents. The variable of key challenges of SSWM in Sana'a City has a Cronbach's alpha value of 0.924 and the improvement measures SSWM in Sana'a City variable has a Cronbach's alpha value of 0 .. Both of the variables are highly reliable as the Cronbach's alpha values are more of 0.8 , which is in agreement with the previous study by Tavakol and Dennick (2011).

\section{Demographic Data}

Figure 3 illustrates the respondents' demographic data. The respondents' details are based on the effect of the factors on sustainable solid waste management, which is (i) income; (ii) highest education level; (iii) age; and, (iv) gender.

Table 6: The Cronbach's alpha value for the key challenges and improvement measures of sustainable solid waste management (SSWM) in Sana'a City

\begin{tabular}{lccc}
\hline \multicolumn{1}{c}{ Variable } & $\begin{array}{c}\text { Number of } \\
\text { Questions }\end{array}$ & $\begin{array}{c}\text { Number of } \\
\text { Respondents }\end{array}$ & $\begin{array}{c}\text { Cronbach's Alpha } \\
\text { Value }\end{array}$ \\
\hline Key challenges of SSWM in Sana'a City & 19 & 17 & 0.924 \\
Improvement measures SSWM in Sana'a City & 9 & 17 & 0.876 \\
\hline
\end{tabular}

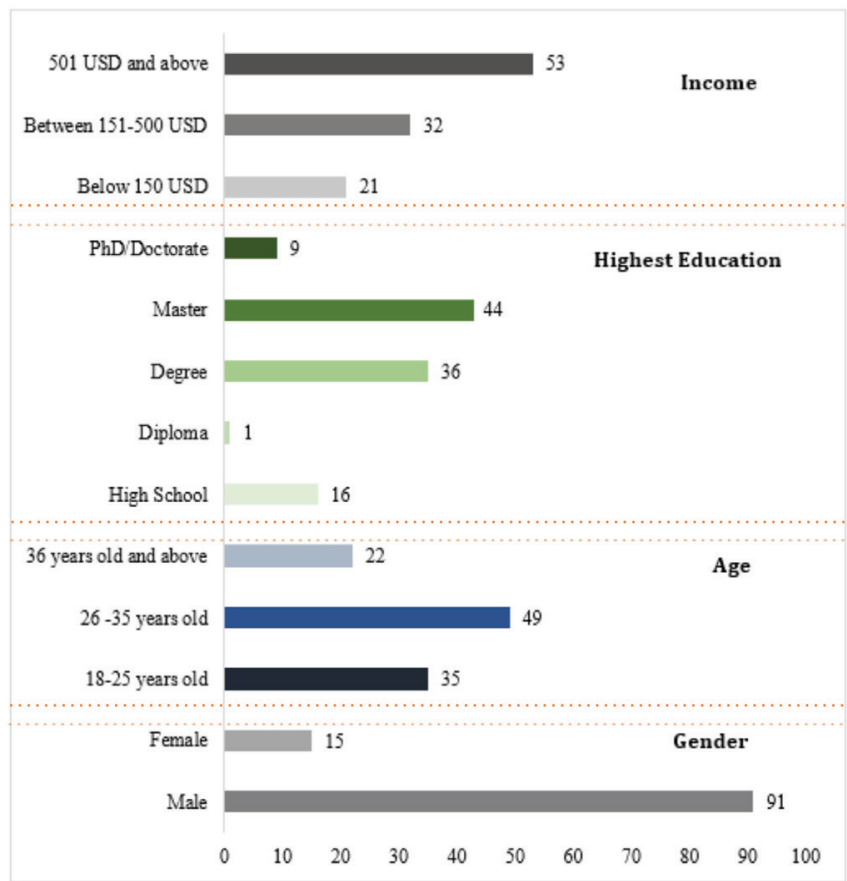

Figure 3: Demographic data respondents from public of Yemen 
Key Challenges of Sustainable Solid Waste Management (SSWM) in Sana'a City, Yemen

In Sana'a City, landfills with capacity limits pose various challenges to the disposal of municipal solid waste, as well as the need to conserve this limited capacity for the future.

Therefore, to reduce the huge volumes of waste, incineration is prioritised to overcome landfill limitations. Table 7 shows the key challenges of SSWM in Sana'a City. The maximum average rank of the key challenges of solid waste management is recycling, with average an RII of $77.8 \%$. It is noticeable that the lack of encouragement for recycling is categorised as the highest challenge from the perception of respondents. In addition, the RII for both lack of recycling companies and the availability of technology is $80 \%$. The markets of recycled materials should be encouraged with increased professionalism by the government.

The limited financial support for recycling leads to the low efficiency of the collection system, as shown in the ranks of 3 and 4, respectively, in Table 7. It has also been shown that while local policymakers are concerned and give priority to solid waste issues, they boost solutions that include more effective disposal processes, stronger maintenance and low-cost recycling technology. Success in recycling relies not only on the extent of involvement, but also on the performance of the machines and infrastructure. The second classification of average rank for challenges is the disposal of waste. High prices for waste disposal, the far distance of the disposal area and limited supply of waste containers are the challenges of disposal waste and their RII are 79.2\%, 76.8\%, and $76.2 \%$, respectively. High price of disposing has the effect on recovery of waste generated, which goes to the value chains or beneficial reuse of waste. The supply of waste facilities significantly affects waste disposal choices, so the infrastructure, equipment and the containers on roadsides are essential for an efficient system.

The steep slope of hills is as obstructive as long distance in disposing of the waste. The third challenge category is the treatment of waste. The RII of lack of knowledge in waste treatment and poor sustainable infrastructure were $78.4 \%$ and $75 \%$, respectively.

One of the factors that affect the treatment of waste is the lack of knowledge of treatment systems through the authorities. In addition, a lack of infrastructure or environmental inefficiencies allow citizens to find alternatives for their wastes, such as domestic incineration and composting, insufficient control of the consistency of the compost being generated and incompatibility of the architecture of the plant with the characteristics of solid waste.

The average of RII of collection and the category of transport was $73.80 \%$ and it is ranked fourth. In most key challenges, RII of collection transport was $75 \%$. The traffic control agencies were absent, and a lack of built-up streets and poor quality of available roads increase the difficulties of waste collection, transfer and transport. A lack of timely information on the collection of waste leads to improper management of the waste. A low number of community waste bins and the limited number of transfer stations hamper efficient management. Collection, transfer, and disposal practices are affected by insufficient infrastructure, such as insufficient manpower and collection/compaction vehicles.

The rank of generation and separation are five (5), with the average RII being 67.6\%. Education and individual awareness contribute greatly to environmental knowledge, how society perceives a problem, and how they decide to face it in their day-to-day actions, especially in the management of solid waste. Furthermore, the high density of houses is one of the barriers in managing waste in developing countries. Cost effectiveness, and acceptability pf the local community are major attributes in achieving an efficient solid waste management system. However, in some of the developing countries, the majority of the people are unwilling to pay the service charge for solid waste management facilities provided to them. 
Table 7: The key challenges of SSWM in Sana'a City

\begin{tabular}{|c|c|c|c|c|c|c|}
\hline Category & $\begin{array}{l}\text { Key Challenges of Solid Waste } \\
\text { Management in Sana'a City }\end{array}$ & Mean & RII \% & Rank & $\begin{array}{c}\text { Ave RII } \\
\quad \%\end{array}$ & $\begin{array}{l}\text { Ave } \\
\text { Rank }\end{array}$ \\
\hline \multirow{6}{*}{ Recycling } & $\begin{array}{l}\text { 1. Lack of encouragement for } \\
\text { recycling }\end{array}$ & 4.10 & 82.00 & 1 & \multirow{6}{*}{77.80} & \multirow{6}{*}{1} \\
\hline & 2. Lack of recycling companies & 4.00 & 80.00 & 2 & & \\
\hline & $\begin{array}{l}\text { 3. Available technology for } \\
\text { recycling is not enough }\end{array}$ & 4.00 & 80.00 & 2 & & \\
\hline & $\begin{array}{l}\text { 4. Limited financial support for } \\
\text { recycling }\end{array}$ & 3.87 & 77.40 & 3 & & \\
\hline & $\begin{array}{l}\text { 5. Low efficiency of the collection } \\
\text { system }\end{array}$ & 3.71 & 74.20 & 4 & & \\
\hline & $\begin{array}{l}\text { 6. Far distance to the collection } \\
\text { area }\end{array}$ & 3.66 & 73.20 & 5 & & \\
\hline \multirow{3}{*}{ Disposal } & 7. High price for waste disposal & 3.96 & 79.20 & 1 & \multirow{3}{*}{77.40} & \multirow{3}{*}{2} \\
\hline & $\begin{array}{l}\text { 8. The far distance of the disposal } \\
\text { area }\end{array}$ & 3.84 & 76.80 & 2 & & \\
\hline & $\begin{array}{l}\text { 9. The limited supply of waste } \\
\text { containers }\end{array}$ & 3.81 & 76.20 & 3 & & \\
\hline \multirow{2}{*}{ Treatment } & $\begin{array}{l}\text { 10. Lack of knowledge in waste } \\
\text { treatment }\end{array}$ & 3.92 & 78.40 & 1 & \multirow{2}{*}{76.70} & \multirow{2}{*}{3} \\
\hline & 11. Poor sustainable infrastructure & 3.75 & 75.00 & 2 & & \\
\hline \multirow{5}{*}{$\begin{array}{l}\text { Collection } \\
\text { and } \\
\text { Transport }\end{array}$} & $\begin{array}{l}\text { 12. Lack planning on waste } \\
\text { collection }\end{array}$ & 3.76 & 75.20 & 1 & \multirow{5}{*}{73.80} & \multirow{5}{*}{4} \\
\hline & $\begin{array}{l}\text { 13. Lack of infrastructure for waste } \\
\text { collection }\end{array}$ & 3.75 & 75.00 & 2 & & \\
\hline & 14. Poor road access for collection & 3.75 & 75.00 & 2 & & \\
\hline & $\begin{array}{l}\text { 15. Limitations on collection's } \\
\text { transport }\end{array}$ & 3.68 & 73.60 & 3 & & \\
\hline & $\begin{array}{l}\text { 16. Lack of information on the } \\
\text { schedule of waste collection }\end{array}$ & 3.51 & 70.20 & 4 & & \\
\hline \multirow{3}{*}{$\begin{array}{l}\text { Generation } \\
\text { and } \\
\text { Separation }\end{array}$} & 17. Lack of awareness program & 3.79 & 75.80 & 1 & \multirow{3}{*}{67.60} & \multirow{3}{*}{5} \\
\hline & $\begin{array}{l}\text { 18. The big number of family } \\
\text { members }\end{array}$ & 3.27 & 65.40 & 2 & & \\
\hline & $\begin{array}{l}\text { 19. High tax for solid waste } \\
\text { management services }\end{array}$ & 3.08 & 61.60 & 3 & & \\
\hline
\end{tabular}

Note: RII= Relative importance Index; Ave $=$ Average

According to the respondents, the containers

Improvement Measures for Sustainable Solid required for the collection of solid waste were not sufficient to meet the demand. The segregation Waste Management (SSWM) in Sana'a City, Yemen of solid waste is poor, demonstrating the critical nature of the problem.

Solid waste disposal and management is an ongoing critical problem in Sana'a City, with an enormous quantity of generated municipal solid 
waste. Environmental safety, public health and the well-being of citizens could not be achieved, while the capacity of the landfill is very limited. Keeping in mind the present conditions and challenges, viable and efficient improvement measures are to be suggested to overcome the situation in Sana'a City, Yemen. Table 8 demonstrates the improvement measures of SSWM in Sana'a City. Compared with current practices in Table 7, the respondents obviously agreed with the importance of both of education and awareness to improve the measures for sustainable solid waste management, with an RII of $83.8 \%$ and $82.4 \%$ respectively. Moreover, providing sufficient technology and proper infrastructure are the priority of technology and facilities to improve the measures of sustainable solid waste management. The RII of introducing penalties for illegal dumping and providing affordable service charges is $82 \%$ and $78 \%$, respectively.

Interested residents can share product designs and models, while they can provide voluntary services to reduce waste generation and enhance the implementation of innovative business models for the reduction of waste. Solid waste facilities are cost-effective like all other service offered, But, in general, the expenses are not recovered. The central government's financial assistance, the involvement of local representatives in waste management concerns, the engagement of service consumers and the effective operation of the funds are important to a modernised sustainability system.

\section{Summary of Results}

In Sana'a City, three-quarters of respondents have solid waste containers, while around a quarter of them do not. In addition, more than half of the respondents do not separate waste as ones that could be reused or recyclable. The lack of both containers and segregation of the waste generated leads to an increase in improper solid waste management in Sana'a City. Furthermore, around half of respondents do not reuse the waste generated. Most of the respondents agree with the importance of segregation of waste and public participation in solid waste management

Table 8: Improvement measures for SSWM in Sana'a City

\begin{tabular}{|c|c|c|c|c|c|c|}
\hline Category & $\begin{array}{l}\text { Improvement measures } \\
\text { for sustainable solid waste } \\
\text { management in Sana'a City }\end{array}$ & Mean & RII & Rank & $\begin{array}{l}\text { Ave. } \\
\text { RII }\end{array}$ & $\begin{array}{l}\text { Ave. } \\
\text { Rank }\end{array}$ \\
\hline \multirow{3}{*}{ Socio-culture } & The importance of education & 4.19 & 83.80 & 1 & \multirow{3}{*}{81.50} & \multirow{3}{*}{1} \\
\hline & $\begin{array}{l}\text { 2. The importance of Awareness } \\
\text { campaigns }\end{array}$ & 4.12 & 82.40 & 2 & & \\
\hline & $\begin{array}{l}\text { 3. The importance of solid waste } \\
\text { celebration's day }\end{array}$ & 3.92 & 78.40 & 3 & & \\
\hline \multirow{3}{*}{$\begin{array}{l}\text { Technical/ } \\
\text { Facilities }\end{array}$} & Provide efficient technology & 4.08 & 81.60 & 1 & \multirow{3}{*}{79.70} & \multirow{3}{*}{2} \\
\hline & $\begin{array}{l}\text { 5. Provide proper infrastructure } \\
\text { (e.g., landfill, collection } \\
\text { system) }\end{array}$ & 3.97 & 79.40 & 2 & & \\
\hline & $\begin{array}{l}\text { 6. Provide suitable equipment } \\
\text { (e.g., waste bin, recycle bin) }\end{array}$ & 3.91 & 78.20 & 3 & & \\
\hline \multirow{3}{*}{ Financial } & $\begin{array}{l}\text { 7. Introduce penalty to illegal } \\
\text { dumping }\end{array}$ & 4.10 & 82.00 & 1 & \multirow{3}{*}{78.70} & \multirow{3}{*}{3} \\
\hline & $\begin{array}{l}\text { 8. Provide affordable service } \\
\text { charge }\end{array}$ & 3.92 & 78.40 & 2 & & \\
\hline & $\begin{array}{l}\text { 9. Involvement of the private } \\
\text { sector to manage solid waste }\end{array}$ & 3.79 & 75.80 & 3 & & \\
\hline
\end{tabular}


and that reflects respondents' awareness. The percentage of respondent's agreement on the importance of sustainable solid waste management and health effect were around $90 \%$ and $80 \%$, respectively.

Figure 4 illustrates that the highest level of the average rank for key challenges of solid waste management depending on the perception of the public is the recycling of materials. This is because of a lack of awareness of recycling, lack of recycling companies and available technologies. Furthermore, the highest rank of improvement measures for sustainable solid waste management is socio-cultural because of the importance of education and the importance of awareness campaigns are ranked the highest in the socio-cultural category. The figure shows the intensity or critical nature of the problem as the colour changes from dark to light for the challenges. While the trend is the opposite, i.e. the intensity changes its colour from light to dark in the case of improvement measures.

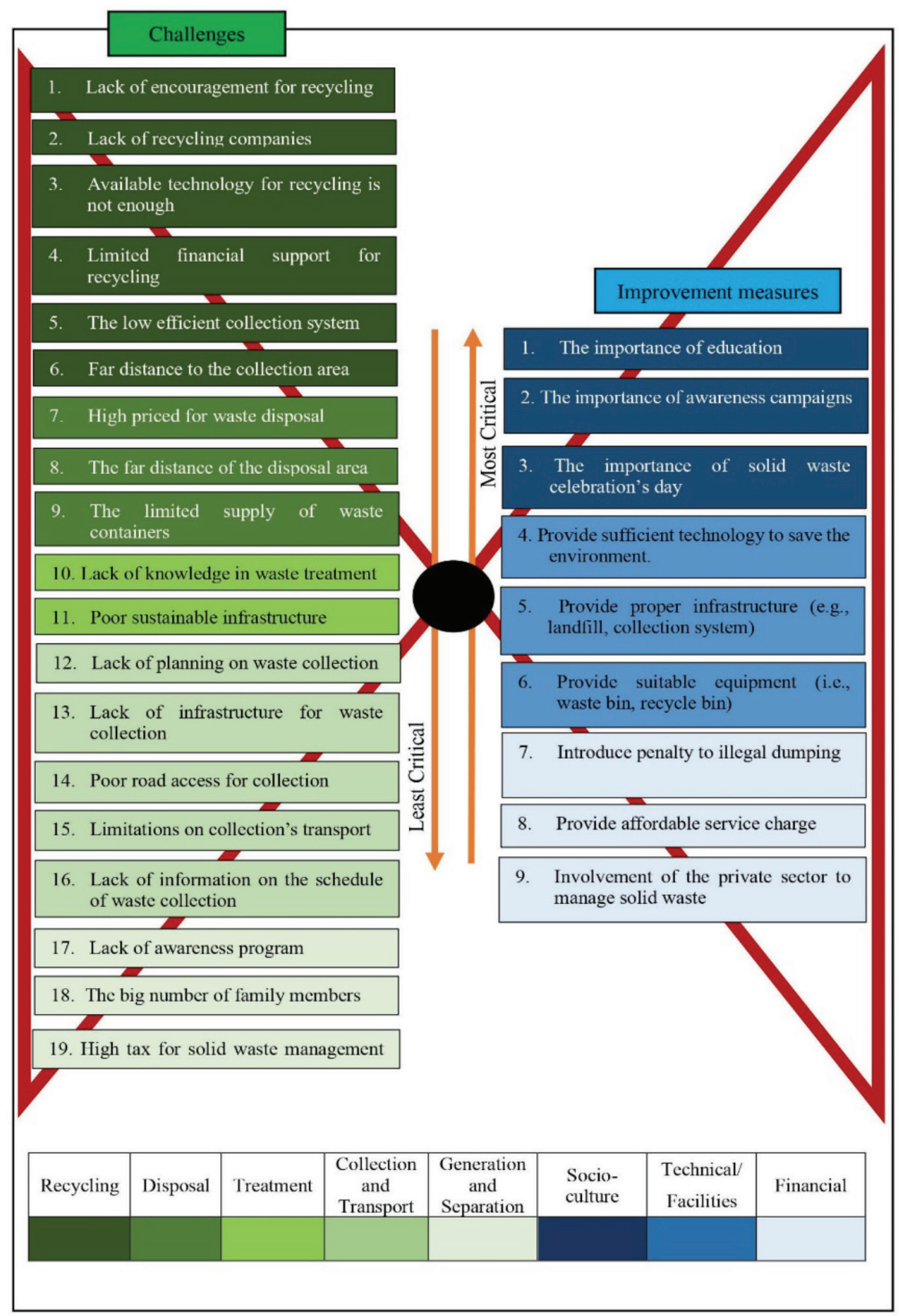

Figure 4: Bowtie of challenges and improvement measures for sustainable solid waste management 


\section{Conclusion}

A solid waste management system is an important requirement for a country to achieve its goal of sustainable environment. This study focuses on the current scenario of solid waste management in Sana'a City, Yemen, key challenges, and the improvement measures suggested on the ground through the survey on the views of the respondents. The highest level of the average rank for key challenges of solid waste management depends on recycling. Therefore, raising awareness of recycling and participation in recycling schemes at different levels (regional and national) may solve this problem. Furthermore, the highest rank of improvement measures for sustainable solid waste management is socio-cultural because of the importance of education and the importance of awareness campaigns ranked the highest in the socio-culture category. The bowtie of challenges and improvement measures shows the intensity or critical nature of the problem as the color changes from dark to light for the challenges. While the trend is opposite, i.e. the intensity changes its colour from light to dark in the case of improvement measures. The study will be helpful to establish and stabilise solid waste management in Sana'a City, Yemen.

\section{Acknowledgements}

The authors like to thank the Malaysia-Japan International Institute of Technology, Universiti Teknologi Malaysia, for the support provided during the completion of this study.

\section{References}

Abarca-Guerrero, L., Maas, G., \& Hogland, W. (2015). Solid waste management challenges for cities in developing countries. Revista Tecnología en Marcha, 28(2), 141-168.

Alam, O., \& Qiao, X. (2020). An in-depth review on municipal solid waste management, treatment and disposal in Bangladesh. Sustainable Cities and Society, 52, 101775.
Ashraf, M. A., Islam, M. R., \& Adnan, S. G. (2015). GIS and multi criteria decision method based approach of identifying appropriate landfill sites for the city of Chittagong. International Journal of Environment, 4(1), 1-15.

Aziz, H. A., Yik, W. C., Ramli, H., \& Amr, S. S. A. (2016). Investigations on the hydraulic conductivity and physical properties of silt and sludge as potential landfill capping material. International Journal of GEOMATE, 10(22), 1989-1993.

Challcharoenwattana, A., \& Pharino, C. (2015). Co-benefits of household waste recycling for local community's sustainable waste management in Thailand. Sustainability, 7(6), 7417-7437.

Connelly, L. M. (2008). Pilot studies. Medsurg Nursing, 17(6), 411.

Cormier, R., Elliott, M., \& Rice, J. (2019). Putting on a bow-tie to sort out who does what and why in the complex arena of marine policy and management. Science of the Total Environment, 648, 293-305.

Cronbach, L. J. (1951). Coefficient alpha and the internal structure of tests. psychometrika, 16(3), 297-334.

Fellows, R. F., \& Liu, A. M. (2015). Research methods for construction. John Wiley \& Sons.

George, D., \& Mallery, M. (2003). Using SPSS for Windows step by step: A simple guide and reference.

George, D., \& Mallery, P. (2003). Reliability analysis. SPSS for Windows, step by step: A simple guide and reference. Boston: Allyn \& Bacon, 222, 232.

Harir, A. I., Kasim, R., \& Ishiyaku, B. (2015). Exploring the resource recovery potentials of municipal solid waste: A review of solid wastes composting in developing countries. International Journal of Scientific and Research Publications, 5(4), 2250-3153. 
Hart, C. (2018). Doing a literature review: Releasing the research imagination.

Holt, G. D., Olomolaiye, P. O., \& Harris, F. C. (1996). Tendering procedures, contractual arrangements and Latham: The contractors' view. Engineering, Construction and Architectural Management.

Hudson, T., \& Hudson, P. (2019). Famous Barriers within the Bowtie Levels Analysis: Creating middle and senior management understanding about the relative importance of management activities. Paper presented at the Abu Dhabi International Petroleum Exhibition \& Conference.

Jarkas, A. M., \& Bitar, C. G. (2011). Factors affecting construction labor productivity in Kuwait. Journal of Construction Engineering and Management, 138(7), 811-820.

Jarkas, A. M., \& Bitar, C. G. (2012). Factors affecting construction labor productivity in Kuwait. Journal of Construction Engineering and Management, 138(7), 811-820.

Jett, Q. R., \& George, J. M. (2003). Work interrupted: A closer look at the role of interruptions in organizational life. Academy of management Review, 28(3), 494-507.

Kameswari, K. S. B., Velmurugan, B., Thirumaran, K., \& Ramanujam, R. (2007). Biomethanation of vegetable market waste untapped carbon trading opportunities. Paper presented at the Proceedings of the International Conference on Sustainable Solid Waste Management.

Liu, Y., Liu, Y., Li, H., Fu, X., Guo, H., Meng, R., . . Wang, H. (2016). Health risk impacts analysis of fugitive aromatic compounds emissions from the working face of a municipal solid waste landfill in China. Environment International, 97, 15-27.

Manzhurov, I., Antonov, K., Kit, M., Berg, D., \& Denisov, D. (2019). Information system for decision support in waste management in the Arctic region of Russia. Paper presented at the AIP Conference Proceedings.

McQueen, R. A., \& Knussen, C. (2002). Research methods for social science: $A$ practical introduction. Pearson Education.

Mian, M. M., Zeng, X., Nasry, A. a. N. B., \& AlHamadani, S. M. (2017). Municipal solid waste management in China: A comparative analysis. Journal of Material Cycles and Waste Management, 19(3), 1127-1135.

Mugambwa, E., \& Kizito, J. (2009). What is Waste Management. URL: http://www. nemaug. orgindex. phpoption $=\mathrm{com}_{-}$ content\&view $=$ article\&id, 69.

Mukisa, P. K. (2009). Public participation in solid waste management: Challenges and prospects: A case of Kira Town council, Uganda. Universitetet i Agder, University of Agder.

Nesan, L. J. (1997). A generic model for effective implementation of empowerment in construction contractor organisations.

Okafor-Yarwood, I., \& Adewumi, I. J. (2020). Toxic waste dumping in the Global South as a form of environmental racism: Evidence from the Gulf of Guinea. African Studies, 79(3), 285-304.

Rafizul, I., Alamgir, M., \& Islam, M. (2011). Evaluation of contamination potential of sanitary landfill lysimeter using leachate pollution index. Paper presented at the Proceedings Sardinia.

Scheuren, F. (2004). What is a Survey?

Suthar, S., Rayal, P., \& Ahada, C. P. (2016). Role of different stakeholders in trading of reusable/recyclable urban solid waste materials: A case study. Sustainable Cities and Society, 22, 104-115.

Tavakol, M., \& Dennick, R. (2011). Making sense of Cronbach's alpha. International Journal of Medical Education, 2, 53.

Taylor, S. J., Bogdan, R., \& DeVault, M. (2015). Introduction to qualitative research 
methods: A guidebook and resource: John Wiley \& Sons.

Umeh, P. P., Friday, K., \& Oji, S. (2019). Geographical analysis of household waste generation and disposal in Taraba state, northeast Nigeria. International Journal, $8(2), 58-68$.
Warunasinghe, W., \& Yapa, P. (2016). A survey on household solid waste management (SWM) with special reference to a periurban area (Kottawa) in Colombo. Procedia Food Science, 6, 257-260.

Zakaria, Z. (2015). Final Account Closing Framework in Construction Project. Universiti Teknologi Malaysia. 